\title{
The first shall be last... - A biblical inversion of leadership traps and pressure-cooker appetites for ambitious statuses
}

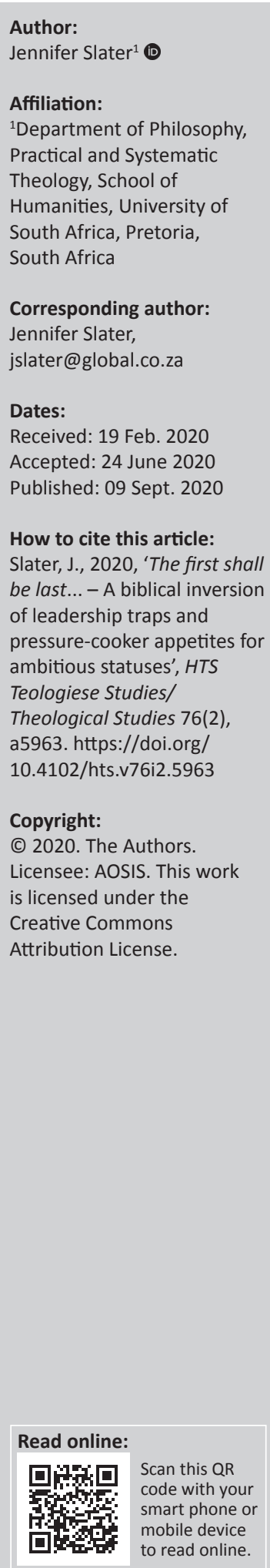

As virtuous leadership appears to be under severe pressure in all areas of life, it is the aim of this article to determine whether this biblical axiom holds suitable and valuable guidelines to counter contemporary leadership traps and assist leaders not to succumb to ambitious leadership cravings. The article determines whether the biblical axiom, the first shall be last and the last shall be first (Mt 20:15-16), holds the capacity to invert the corrupt pressure-cooker drives for both religious and secular leadership ambitions. It examines the biblical and ethical wisdom of this teaching as well as the authoritative relevance it holds for leadership formation and practice. It determines whether a biblically infused value system still contains the moral capacity that contributes to the observance of resonant and ethical leadership capable of reversing pervasive situations of corrupt and incompetent leadership. In addition, the article contemplates the Christian weight of this biblical axiom to place those who are last, first in the service of leadership. In the same vein, it examines some of the 'leadership traps' experienced by persons who occupy lay, clerical, professional and secular positions. It endeavours to offer reflective biblical, moral and spiritual solutions that arise from the spirituality offered by Matthew 20:16 to current leadership demises.

Contribution: The theme of the Leadership conference where this article was presented was the biblical verse: 'The first shall be last and the last shall be first' (Mt 20:15-16). The article focuses directly on the implications of the biblical axiom and relate, as well as, translate it to leadership difficulties as experienced today.

Keywords: Christological leadership; Superiority; Ethnocentrism; Aversion; Perversion; Spawning dissonance; Trapped leadership; Bottom-line-demands.

\section{Introduction}

This biblical axiom, 'many who are first will be last, and the last, first', appears in all three of the synoptic gospels: Matthew 19:30; 20:16; Mark 10:31; and Luke 13:30. At the end of the parable, the phrase is actually reversed: So, the last shall be first, and the first last (Mt 20:15-16). What follows is an exploration of the applicability and relevance of the parable readings to leadership feats and demises. Moral leadership is under serious pressure, and this article determines whether this biblical saying holds suitable and valuable Christian guidelines to counter contemporary leadership traps and assist leaders to withstand ambitious leadership appetites. Leadership traps result in many avarice conduct such as compromising one's values, falling into dysfunctional behaviour, belittling others, being narcissistic, being incompetent and lacking the necessary leadership skills and morals. To fall into leadership traps is counterproductive, and according to Argyris (2010:2), it can lead to unfortunate calamities. Leadership traps, declares Argyris, inhibit effective problemsolving and the detection and correction of errors and learning, especially when learning is needed the most. Leadership traps are known to be anti-learning as well as anti-corrective. Argyris (2010:2) is of the opinion that leadership snares facilitate blaming others for creating and maintaining traps. Toxic leadership practices come as a result of a leader's entrapment in unhealthy habits. This article looks at how this parable provides crucial measures to reduce leadership traps and to offer spiritual and biblical reasoning processes that will make sense of the situations in which leaders lead. Christological leadership that is exercised with humility appears to be counter-cultural because it appears to move away from hierarchical and patriarchal leadership.

\section{Parables and their multiple levels of meaning}

According to Robbins (1996:1-4), social-rhetorical criticism (SRC) is a hermeneutical method that is used to analyse and interpret the world in which a 'biblical writer lived and the contemporary world

Note: Special Collection entitled Christian Leadership, sub-edited by Wessel Bentley (UNISA). 
by comparing and contrasting values, convictions, and beliefs inside the sentences, paragraphs, and discourses' (Robbins, in Mizzell \& Huizing 2018:2). The parable, according to Matthew 20:16, which cites that the first shall be last and the last shall be first', is situated in the Hellenistic-Roman world and illustrates the dreadful conditions of casual labour. Employers looked in the agora (the Greek marketplace) ${ }^{1}$ of the city for unemployed men waiting to be hired. Such men would work for as little as the employer decided to pay. A denarius is a coin that represented subsistence wages at the lowest level for a day. As the day goes on and more labourers are needed, more are hired at the same wage. The parable instructs that the labourers grumbled; the dissatisfaction might seem reasonable to us, but the capitalists of the ancient world were masters of their money, as the employer in the parable says (Mt 20:15), '[d]on't I have the right to do what I want with my own money? Or are you envious because I am generous?' In the King James translation, it reads, '[i]s it not lawful for me to do what I will with my own? Is your eye evil, because I am good?' (Mt 20:15). The labourers are rebuked not for dissatisfaction with what they receive, but for the dissatisfaction that others receive as much; however, the employer insists on his right to be generous. The prevailing sentiment is by giving to the one, the employer takes nothing away from the other. This formed part of the economic climate that prevailed during the time of Jesus' earthly ministry. The parable communicates the absolute equality in the blessedness of the life to come, but the quality of that life starts in the present moment.

Judging from the facts of the parable, it is clear that there is no reversal of fortunes; rather, it illustrates the generosity of God. Vineyard is the symbol of Israel's wage; Denarius was the normal day's wage; the Boss hires, and he looked for labourers at the marketplace, because this is where those who looked to be hired will normally gather; the wage is just, but unspecified; and the eleventh hour is normally about an hour before sunset, when work ceased (Brown, Fitzmeyer \& Murphy 1969). The labourers wanted to work, but suffered unemployment; their idleness is not laziness. However, work is more honourable than to do nothing. The wage is the same, yet it is not truly equal, because the boss is more generous to the latecomers. What was the motivating factor: the intention to work? Yet, the householder commits no injustice. This reflects the classic definition of justice, that is, to render what is due to each one who worked. A just wage is connected to just work, and meaningful leadership is related to our understanding of work. Koesterbaum (2002:4) says: 'Work makes meaning. How we relate to work, is a responsibility and protecting the sense of destiny, greatness and dignity by how we choose work and how we do it'.

The meanings of parables are multilayered, and in this parable, the Jews and the Gentiles are compared in the reign of God. McKenzie (2015:99) puts it as follows: 'the Gentiles are admitted late, but they are admitted on an equal standing with the Jews'. The Kingdom of God does not discriminate, but upholds the principle of equality: 'Those who were hired last

1.Agora in ancient Greece is an open space in a town where people gathered, in this case a marketplace (public square/arena?) worked only one hour', they said, 'and you have made them equal to us who have borne the burden of the work and the heat of the day' (Mt 20:12). The controversy over the admission of Gentiles was a major problem of the Apostolic Church, and thus, for this reason, the parable proposed a solution as indicated in Matthew 20:16, stating that ' $[t]$ he first shall be last and the last shall be first'. The axiom does not really suit the situation, because it is not a question of a reversal of positions, unless we suppose that the admission from the Jewish Christian perspective claims that the admission of the Gentiles on an equal plane was a degradation of and for the Jews.

The last shall be first: the reversal of fortunes is attributed to the generosity and goodness of God, God's love for the needy, not to any class vindictiveness. The equitable meaning of the parable is that it does not matter when one is admitted to the Reign of God; one is admitted to full. The Kingdom of God does not become the property of those who first sought admission, even if they regard themselves as its employers or leaders. Koesterbaum (2002:6) says just to have money or authority does not make someone a leader. He continues stating that one, however, 'feels gratitude towards real leaders, for they have the courage to serve others in circumstances that many individuals are avid or simply cannot handle'.

\section{Alignment of values between leaders and followers}

It is quite apparent from the parable that the landowner and the workers were not on par concerning their values. 'Those who were hired last worked only one hour', they said, 'and you have made them equal to us who have borne the burden of the work and the heat of the day' (Mt 20:12). For leaders and followers to establish successful working relationships value, proximity should exist between them, and the followers should most likely adopt the values of authentic leaders. According to Mizzell and Huizing (2018:21), the adoption of values does not occur just by osmosis. What is required is sense-making, sense-breaking and sense-giving communication (Hoelscher, Zanin \& Kramer 2016). According to Hoelscher et al. (2016), sense-making assigns meaning to experiences, and sense-breaking occurs when new realities require individuals to re-examine its alignment with a set of new values and new meanings that results in a paradigm shift (Hoelscher et al. 2016; Kuhn 2012). In reality, the process is not as simplistic as there are various interpretations of the sense-breaking event, a variety of sense-giving messages and some degree of spectrum to sense-making values, and as such, the movement to new sense-making can be filled with conflict and opposition (Mizzell \& Huizing 2018:21). When a discrepancy in values exists between leaders and followers, the result could be that both leaders and followers get trapped in unhealthy leadership scenarios.

\section{Being trapped in the demand for superiority and ethnocentrism}

In the parable, Jesus was talking to the Jewish religious leaders who thought, because of the rabbinic leadership 
positions, that they were first in Israel. They were under the impression that they would be the first to enter the kingdom of God because they considered themselves both privileged and chosen. The Gentiles, on the other hand, were the socalled last or the late comers. According to Deuteronomy 7:6-7, the Jews were God's chosen people, and the religious leaders, therefore, presumed that heaven or eternal life was guaranteed to them by the mere fact that they were Jewish by race and identity. As Jesus ministered to the Jews first, and the apostles preached the gospel to the Jews on the Day of Pentecost (Ac 2), the understanding was that the gospel was to be given to the Jews as a divine principle and thereafter to the Gentiles. Romans 9 also reveals that the promises were given to the Jews first and prophetically promised to the Gentiles.

Jesus told the religious leaders that they were first in God's plan, but because they rejected him, they shall be the last. The parable concluded by reversing the phrase the first will be last and the last, first. He says, Some are last who will be first and some are first who will be last. Both phrases make it clear that salvation or eternal life is not earned by one's ranking in this life, that is, God's prerogative: the owner of the vineyard decides. Through the lens of the Hebrew and Christian scriptures, earthly rank will not automatically translate into an inverse heavenly rank. A person's position or prominence in this life does not provide the person with a particular advantage to gain eternal life or salvation. It has been made clear in the scriptures that eternal life is for those who believe in God, and it is more than intellectual knowledge about God, it is relational.

Whilst a person may be first with material wealth, rank and status, in the eyes of God's reign, salvation or eternal life is not earned by wealth, or status or honour. It is quite remarkable how nations or groups of people fall trap to the idea of elevating themselves to be God's chosen people or race and consequently oppress and demean those who are different. The vicious sequence of an unfortunate reality results: those who are oppressed and once liberated oppress others. The first oppress the so-called last, and when the last is liberated, they oppress the first.

\section{The concept: Chosen people of God as leaders}

The Jewish idea of being chosen by God is found in the Torah and is elaborated in the later books of the Hebrew Bible (Dt 7):

You are a people holy to the Lord your God. The Lord your God has chosen you out of all the peoples on the face of the earth to be his people, his treasured possession. (v. 6)

Yahweh chose the Israelites and the Israelites chose Yahweh. The covenant between Yahweh and Israel, facilitated by Moses, the leader at Sinai, is the attested covenant par excellence in the Old Testament. 'This covenant' as indicated by Holladay 1995):

$[W]$ as understood to bind Yahweh, and Israel together, giving rise to the often repeated formula: I will be your God, and you shall be my people (Ex 6:7; Lv 26:12; Dt 29:13). (pp. 26-27)
The early Christians, in particular, believed that they have some share with the Jews in the status related to the concept Chosen People. Others are of opinion that the Jews no longer hold the Chosen People status because they rejected Jesus. And again, there are those who ascribe to supersessionism (or replacement theology), who believe that Christians have replaced the Jews as God's chosen people (Holladay 1995:26-27). For this interpretation, those who believe in replacement theology select New Testament references such as Galatians 3:28-29 to support their perception that the followers of Jesus have now replaced the Israelites as the chosen of God, and they are also the heirs to God's promises to Abraham, and hence, Paul's axiom that in Jesus Christ, 'there is neither Jew nor Greek, slave nor free, male nor female, for you are all one in Christ Jesus. If you belong to Christ, then you are Abraham's seed, and heirs according to the promise'.

However, with the 'Chosen status' came the responsibility of leadership and individuals, such as Moses, were allocated prime responsibilities. In this sense, biblical leadership is always connected to a divine calling related to the will of God to perform a specific task and to take full responsibility thereof. Their leadership was deeply rooted in their relationship with Yahweh, and often, they had to discern God's presence and direction in crisis situations. The Exodus event shaped the leadership character of all those who participated in this responsibility. The Exodus event 'will never be effaced from the memory of Israel' (Hebblethwaite 1993:105), and it was the task of the leaders to guide the Israelites from hardship and oppression to liberation. Many believers who had experienced oppression associated their liberation as being chosen by God similar to the Israelites. This Chosen People concept helped the Jews to form their identity, which lends credence to their sense of belonging. It assisted them to withstand the disintegrative forces of modernity (Van Niekerk 2018). Several times in history, the views of being a Chosen People became connected with racial superiority and ethnocentrism.

This was witnessed in South Africa when the Afrikaners perceived themselves as God's Chosen people when they searched liberation from British oppression. They were Calvinists, and Du Toit (1983:925) states that they 'identified their own history with that of Israel in the Old Testament and like the Jews' who regarded themselves specially selected. They believed that they were also endowed with a divine mandate, just like the Jews, and this motivated their 'selfunderstanding' (Du Toit 1983:925).

Du Toit (1983:920) argues that the origins of Afrikaner nationalism, its associated racial ideologies and the consequent apartheid regime that was imposed on South African society by the National Party governments have often been ascribed to this obdurate strain of 'Calvinism'. The 17th-century Calvinist thought, a kind of primitive Calvinism, which provided much of the rationale for the Great Trek, caused the Voortrekkers and the Republican Afrikaners to perceive themselves as 'a chosen covenanted people', similar 
to the Israelites of the Old Testament. This, says Du Toit (1983:920), 'has been used to explain and justify racial inequality and repression in latter-day Afrikaner-dominated societies'.

By so doing, the Afrikaners situated themselves amongst the chosen and thus the first. The inversion from the superior nation or leader, or the oppressor to the oppressed and the liberated to the oppressor is intricately related to leadership that becomes trapped in some ideology or social identification. This was also apparent in the German Nazi administration during the Second World War, whereby their Herrenrasse or Herrenvolk idea, the superior concept, gave way to the Herrenmenschen or Master race or Master human concept versus the Untermenschen (a person of inferior status). If you were not Aryan, you were eliminated. This ardent clamour for superiority, a worldwide leadership trap, inevitably involves positioning people first and last, superior and inferior.

This is also currently observable in South African politics, where the desire for inversion gives way to the trap of revenge politics. Julius Malema, the leader of the Economic Freedom Fighters (EFF), states repeatedly how he wants to see white domestic workers in South Africa in the next 10 years, making the so-called first, last (ANA Reporter 2019):

Monday, 19 February 2019: Durban - Economic Freedom Fighters (EFF) leader Julius Malema, told hundreds of supporters in KwaZulu-Natal that he longs for the day when white South Africans serve black citizens.

'I don't want blacks to work for whites, I want you to work for yourselves; white people will work for you. That will be true freedom. You must teach them how to carry babies on their back. They must feel what our parents have been feeling,' he said.

'I long for the day when a white man will be driving a tractor on your farm. I long for a day when [Democratic Alliance $M P$ John] Steenhuisen will be driving a tractor on [EFF national spokesperson Mbuyiseni Ndlozi's] farm. White privilege will come to an end under EFF,' Malema said, to cheers from the crowd. (n.p.)

Leadership greatness is acquired more so by personal liberation rather than social, political and economic liberation; as is said by Koesterbaum (2002:24), the liberation that is accompanied by a conversion experience results in transformed thinking and acting, a change of attitude and mindset. If the leader is not prepared to radically change perceptions and concepts with respect to human potential and culture, what follows is more oppression and corruption.

There exists no spiritual leadership maturity in revenge politics because it is capsizal and neither in politics that oppress people. As Delbecq (2008:486) says, inner spiritual growth matters, and the spiritual dimension of leadership is a legitimate and enriching perspective, without it leadership goes astray. Spiritual intelligence and moral maturity define leadership, Christian leadership, and the moral dimension of all leadership remains essential. Whilst the concept of 'Chosenness' may be offensive to those who are not Jews, both Christians and Jews alike are of opinion that to possess the chosen status is by designation a humble status; however, it carries with it accountability and sacrifice, rather than favour. It is very much linked to leadership and the quality of responsible leadership. The task of leaders that embrace values is to equalise and to align all people by eliminating situations of oppression. Leaders are there to facilitate transformation, to redress and remove injustices and societal attitudes so as to bring all people into the mainstream of development and change (Ncube 2010:77). Leadership without an ethic of spirituality inevitably gives way to many conflicts, oppressions, failures and scandals.

\section{Leadership trapped in the lowness of perversion}

In the parable, the workers who came first and worked the longest questioned the generosity of the landowner who paid everyone the same wage. 'Call the workers and pay them their wages, beginning with the last ones hired and going on to the first' (Mt 20:8). Those who were hired first expected more money and objected that they were equalised with those who only worked for an hour '...' they said, 'and you have made them equal to us who have borne the burden of the work and the heat of the day' (Mt 20:12). The landowner asked why they questioned his generosity.

Leadership responsibility for the Israelites is linked to covenant fidelity, which requires that those in leadership govern with justice, equity and consideration for the poor. Biblical leadership translates the teachings of the prophets into that which is imperative for leaders to be agents of social responsibility (Responsibility 2015) in whatever circumstances they find themselves and wherever they live. The messages of the prophets were not only addressed to Kings and leaders, but the responsibility to act with justice and righteousness were also entrusted to all people under their jurisdiction (Cochran \& Van Drunen 2013:2013). In the words of Koesterbaum (2002:20), a good 'leadership mind can hold opposing and contradictory feelings at one and the same time'. Koesterbaum (2002:27) says that at the centre of the leadership, mind is greatness and statesmanship. Greatness may not be a sufficient condition for effective leadership, but it is surely a necessary one. A leader leads by modelling spiritual greatness. Koesterbaum (2002:27) continues to describe philosophical greatness as 'the commitment to relinquish mediocrity forever, since greatness is an intrinsic value, an inherent good and pure virtue'. As greatness is a 'good in and of itself, it is to be sought for its own sake', because it enables the human spirit and honours the fact that humans possess the gift of life and constitutes our meaning for being on earth. So to question the motives of a good and generous leader is tantamount, in this instance, to questioning impartiality and egalitarianism.

In his book Leadership: The inner side of greatness..., Koesterbaum consults the insights of religion, philosophy and psychiatry in the approach to magnanimous leadership. $\mathrm{He}$ is of the opinion that when spirituality is at work in the 
practice of leadership, then leadership can reach the distinctions of ethics and responsibility. When leadership experiences a total breakdown of ethics, then it falls into the trap of corruption and immorality. Embracing free will and responsibility as prime values assists in putting integrity back into leadership (Koesterbaum 2002:xii).

The employer in the parable applied the noble statuses of free will. According to Koesterbaum (2002:27), the philosophical definition of greatness is that 'leadership greatness' is always a 'struggle against mediocrity; it is the upgrading from good to excellent. At a very profound level, greatness is a struggle against nihilism - the descent into nothingness'. In other words, leadership greatness involves transcending the self as an inherent value because the 'core values of leadership embrace community, democracy, social justice, caring and equity'. According to Koesterbaum (2002:8), to undertake the task of leading implies understanding the consequence of one's action or inaction. Leading, therefore, implores achieving access to the will and claiming the power of one's freedom, and it requires changing how one thinks and acts at will. So for the landowner to give all the workers the same wage was a decision that he took as an employer, and by taking charge of his free will, he also took charge of his humanity; according to Koesterbaum (2002:8), the biblical story of creation underscores this point. Leading thus requires taking ownership of the meaning of personal responsibility and accountability and this is rooted in one's free will. So when those came who were hired first, expected to receive more (Mt 20:10), the landowner in the parable did not succumb to their expectations; he acted with social responsibility, which was not trapped in social expectations.

\section{Leadership trapped in spawning dissonance}

Challenges are the crucible of greatness, and exemplary leaders are tested by challenges, which bring them face-to-face with their commitment, values and grittiness (Kouzes \& Posner 2010:xxiii). The landowner in the parable was challenged when the workers who worked the whole day said (Mt 20):

These who were hired last worked only one hour,' they said, 'and you have made them equal to us who have borne the burden of the work and the heat of the day'. 'But he answered one of them, 'I am not being unfair to you, friend. Didn't you agree to work for a denarius? Don't I have the right to do what I want with my own money? Or are you envious because I am generous? (vv. 12-15)

Whilst the landowner was challenged, the social and economic expectations of the workers were also challenged in turn. Once a leader communicates his or her values with conviction and authenticity, it is easy for workers, employees or followers to be persuaded towards a happy compromise.

Exemplary leaders are exemplary, and credibility is the foundation of their leadership. People want to know what the leader stands for and wish to believe in their values, drive and commitment, especially when people have become cynical about their leaders and institutions (Kouzes \& Posner 2010:1). The leader has to believe in himself or herself, so that others can also believe in their leader and have a positive impact on them.

The power of toxic leadership poisons the emotional climate of a workplace (Goleman \& Boyatzis 2013a:1), and great leadership works through the emotions. Emotionally intelligent leadership arouses passion and enthusiasm and keeps people motivated and committed. Goleman and Boyatzis (2013:5) instruct that the emotional task of the leader is primal and need to drive the collective emotions in a positive direction so as to clear the smog that is created by toxic emotions. They claim that by pushing people's emotions towards the 'range of enthusiasm, performance can soar, if driven towards rancor and anxiety they are thrown off stride'. Followers always look to a leader for supportive emotional connections for empathy (Goleman \& Boyatzis 2013:5); when leaders bring out the best out of others, the effect is called resonance, and when leaders drive the negative, leaders spawn dissonance.

Emotional intelligence enables leaders to handle themselves and their relationships; this, say Goleman, Boyatzis and MaKee (2013a:6), is made possible by means of neurological mechanisms of primal leadership. They explain that emotional intelligence and good relationship lie in the design of the human brain. According to Goleman, Boyatzis and MaKee (2013a:6), scientists refer to the open-loop nature of the limbic system, our emotional centres. The opposite, the closed-loop system such as the circulatory system is selfregulatory. Goleman, Boyatzis and MaKee (2013a:6) explain what happens in the circulatory system:

[S]ystem of others around us does not impact our own system. An open-loop system depends largely on external sources to manage the self. We rely on connections with other people for our own emotional stability. (p. 6)

They continue to state that according to scientists, the open loop is an 'interpersonal limbic regulation', whereby one person transmits signals that can alter hormone levels, sleep rhythms and even the immune function of the body. They explain that an open-loop design of 'the limbic system means that other people can change our very physiology - and so our emotions' (Goleman, Boyatzis \& MaKee 2013a:7).

Leaders who tend towards negative moods and negative emotions such as chronic anger, anxiety or a sense of futility powerfully disrupt or hijack attention from the task at hand. An emotional hijacking undermines mental efficiency and a sense of well-being. The opposite, namely positive emotions, results in a sense of feeling good, and this lubricates mental efficiency (Goleman \& Boyatzis 2013b:12-13). Authentic leaders lead with the heart, as well as with the head (Kouzes \& Posner 2010:xxxii). Love is the motivation that energises leaders who give as much to others and their clients and the mission that they are serving. Positive leaders make others feel important and appreciated. According to the neuro- 
anatomy of leadership, good leaders bring out resonance and poor ones create dissonance.

\section{Leadership trapped in bottom-line demands: Profits first and people last}

If Christian leadership does not embrace biblical principles, it will compete with bottom-line demands. In worldly leadership, the first is first and the last is last, but not in Christian terms. Positions bring wealth and honour to some, whereas, in Christian terms, leadership is meant to form part of the divine principle, which does not indulge in worldly privilege or in the exploitation of people. Christian leadership is not measured by wealth and status. Christian leadership imbues trust and belief and obeys the will of God. According to Mark 10, servant leadership is the Jesus 'tool' for leaders who wish to succeed:

Not so with you. Instead, whoever wants to become great among you must be your servant, and whoever wants to be first must be slave of all. For even the Son of Man did not come to be served, but to serve, and to give his life as a ransom for many. (vv. 43-45)

Larry Julian in his book God is my CEO writes that leadership in conjunction with management extends across races, nationalities, religions and genders. Whilst we desire to do the right thing, we often succumb to the short term, bottomline demands of daily life (ed. Julian 2014:24). The reason is because we operate in two separate worlds: a deeply personal, private spiritual world and a very public demanding, competitive secular world. For the most part, these two worlds clash in their values, beliefs and principles, and leaders are caught in the middle (ed. Julian 2014:27). He asks whether one can live by God's principles and suffer whatever negative consequences come one's way. He asks: can one be both ethical and profitable? Can one do what is right and be successful in a competing bottom-line world? Can we honour God, serve others and fulfil our professional obligations?

To these questions, Julian (ed. 2014) answers a resounding 'YES!':

Biblical principles and bottom-line success are not opposites. One can honour God, serve others and fulfil one's professional obligations. One can integrate God's principles with unique talents, skills and character and create powerful partnerships for being successful in the world without becoming of the world. (pp. 25-26)

\section{Bottom-line pressures}

As explained by Julian (ed. 2014:148), the meaning of bottomline pressures derives from the 'final line in the accounts of a company or organization, stating the total profit or loss that has been made'. The aim of Christological principled leadership is to move from profits first and people last. Biblical leadership seeks the vision, the standards, values and goals that involve both employees and employers in the process. This leader puts the needs of all others before his or her own, because the biblical leader is defined as one who serves (ed. Julian 2014:148). Bottom-line pressures control the leader as 2 Peter 2:19: reads: 'For a person is a slave to whatever has mastered him or her'. Hence, leaders who become slaves to bottom-line pressures become professionally ineffective and personally burnt out. To become slave to the bottom-line world is to focus on achieving results, monetary success, work to please people, don't surrender, it means being first, to be a slave to the urgent and to reach profitable outcomes by hounding workers or followers. To adhere to God's principles implies to serve a purpose, focused on growth, people's welfare is the priority, to do the right thing regardless of the outcome, to utilise the freedom of choice and practice unconditional love (ed. Julian 2014:24).

God's design of leadership has a solid foundation and is built to grow stronger over time and pressure. The effective leadership model utilises time and pressure to yield wisdom, growth in character and maximum productivity. God's wisdom, one's spiritual core provides strength, purpose and direction and balances and leverages one's skills and abilities. Thousands of leaders possess great external leadership skills, but no inner character. There are also many people of great character who do not have the necessary leadership skills. World leaders who succumb to bottom-line pressures weaken the person: prioritise profits over principles and reduce value, provide nothing, but bottom-line results. Godly leaders are strengthened by pressure, prioritise principles rather than profits, strengthen character and produce legacy. Power and authority have little to do with money and position and everything to do with character and aligning one's actions with one's principles.

\section{Leadership as an affair of the heart}

Authentic leadership needs to embody certain qualities such as values, trust and commitment in order to create a better world (Mt 20):

About five in the afternoon he went out and found still others standing around. He asked them, 'Why have you been standing here all day long doing nothing?'7 'Because no one has hired us', they answered. He said to them, 'You also go and work in my vineyard'. (vv. 6-7)

Many authentic leaders have come to appreciate the value of spirituality at work in the employment of leadership that insists in reaching greater heights of ethics and responsibility. The parable in Matthew reveals how the landowner shows perception and understanding of the value of work and how a worker ought to relate to work: it is a responsibility, and leaders are to protect the sense of destiny and dignity related to work. Work, says Koesterbaum (2002:4), creates meaning, and a person's attitude towards work results from a person's personal belief that generates behaviour and behaviour has a consequence. 'Ultimately' he says: 'you become what you believe and do every day' (Koesterbaum 2002:27). The parable points out that it is not a matter of profits first, but people first, because leadership sets the tone for worker's productivity. Leadership sets the vision, the values and the goals and by so doing involves employees and employers in 
the one process, and puts the needs of all others before his or her own. Scriptures define a leader as one who serves: 'Not so with you. Instead, whoever wants to become great among you must be your servant, and whoever wants to be first must be slave of all' (Mark 10:43-44).

This bottom of the world servant leadership is the tool scripture provides leaders with to succeed. To have money or authority does not constitute leaders, but leadership is a way of thinking, it is an attitude and a mindset that is cultivated by a practical spirituality imbued by Christian values. Christian leadership traits, as summarised by Bekker (2008), are related to the honour and glory of Christ; they express competence and moral character, demonstrate high levels of personal self-control, delegate tasks, act in a decisive and clear manner, have a:

[F]irmness of conviction that leads to leadership excellence; strives to live a balanced life; have clear priorities and value personal, family, community, and social relationships and is steeped in faith and prayer, this constitutes a devotional life that allows leaders to employ discernment and wisdom in their leading. (p. 145)

However, it can be deduced that unless gospel values are in alignment with servant leadership, it will fail to be effective and will not accomplish its intended outcomes, which is to create a more caring and loving world for all (Mizzell \& Huizing 2018:12).

\section{Conclusion}

The article has set out to examine whether the biblical axiom: The first shall be last... holds the capacity to invert the corrupt pressure-cooker drive for both religious and secular leadership ambitions. The biblical and ethical wisdom of this teaching still holds authoritative relevance for leadership formation and practice. A biblically infused value system still contains the moral capacity to contribute to the practice of resonant leadership and to reverse widespread situations of corrupt and incompetent leadership. It carries Christian credence and wisdom to place those who are last or disadvantaged first in the service of leadership; it possesses the authority to equalise that which is unequal. Leadership traps are experienced by lay, clerical, professional and secular leaders; and reflective biblical, moral and spiritual solutions to current leadership demises are housed in the spirituality of leadership offered by the scriptural and interpretative teachings offered by Matthew 20:16. This is based on the reliance that without God nothing beneficial can be done.

\section{Acknowledgements Competing interests}

The author declares that she has no financial or personal relationships that may have inappropriately influenced her in writing this research article.

\section{Author's contributions}

J.S. is the sole author of this research article.

\section{Ethical considerations}

This article followed all ethical standards for research without direct contact with human or animal subjects.

\section{Funding information}

This research received no specific grant from any funding agency in the public, commercial or not-for-profit sectors.

\section{Data availability statement}

Data sharing is not applicable to this article as no new data were created or analysed in this study.

\section{Disclaimer}

The views and opinions expressed in this article are those of the author and do not necessarily reflect the official policy or position of any affiliated agency of the author.

\section{References}

ANA Reporter, 2019, '\#JuliusMalema tells EFF supporters: We want white people to be our domestic workers', IOL, viewed n.d., from https://www.iol.co.za/news/ politics/juliusmalema-tells-eff-supporters-we-want-white-people-to-be-ourdomestic-workers-19496146.

Argyris, C., 2010, Organizational traps: Leadership, culture, organizational design, University Press, Oxford.

Bekker, C.J., 2008, 'Towards a theoretical model of Christian leadership', Journal of Biblical Perspectives in Leadership 2(2), 142-152.

Brown, R.E., Fitzmeyer, J.A. \& Murphy, R.E., 1969, The Jerome Biblical commentary, Geoffrey Chapman, London.

Cochran, R.F. \& Van Drunen, D., 2013, Law and the Bible: Justice, mercy and lega institutions, IVP Academic Intervarsity Press, Westmont, IL.

Delbecq, A.L., 2008, 'Nourishing the soul of the leader: Inner growth matters', in J.V. Gallos (ed.), Business Leadership: A Jossey-Bass Reader, 2nd edn., pp. 486-515, Jossey-Bass, San Francisco, CA

Du Toit, A., 1983, 'No chosen people: The myth of the Calvinist origins of Afrikane Nationalism and racial ideology', The American Historical Review 88(4), 920-952.

Goleman, D., Boyatzis, R. \& McKee, A., 2013a, Primal leadership: Unleashing the power of emotional intelligence, Harvard Business Publishing School, Boston, MA.

Goleman, D., Boyatzis, R.E. \& McKee, A., 2013b, Primal leadership, with a new preface by the authors: Unleashing the power of emotional intelligence, Harvard Business Review Press, Boston, MA.

Hebblethwaite, P., 1993, 'Let my people go: The Exodus and liberation theology', Religion, State and Society 21(1), 105-114. https://doi.org/10.1080/09637499308431582

Hoelscher, C.S., Zanin, A.C. \& Kramer, M.W., 2016, 'Identifying with values: Examining organizational culture in farmer markets', Western Journal of Communication 80(4), 481-501. https://doi.org/10.1080/10570314.2016.1163613

Holladay, W.L., 1995, Long ago God spoke: How Christians may hear the Old Testament today, Fortress Press, Minneapolis, MN.

Julian, L. (ed.), 2014, God is my CEO: Following God's principles in a bottom-line world, Adams Media, New York, NY.

Koesterbaum, P., 2002, Leadership: The inner side of greatness: A philosophy for leaders, Jossey-Bass Publishers, San Francisco, CA.

Kouzes, J. \& Posner, B., 2010, The truth about leadership: The no-fads, heart-of-thematter facts you need to know, Jossey-Bass Publishers, San Francisco, CA.

Kuhn, T.S., 2012, The structure of scientific revolutions, The University of Chicago Press, Chicago, IL.

McKenzie, J.L., 2015, Commentary on the Gospel according to Matthew, Wipf \& Stock Publishers, Eugene, OR.

Mizzell, N. \& Huizing, R.L, 2018 'When servant leadership fails: The importance of aligning values', Journal of Biblical Perspectives in Leadership 8(1), 12-24.

Ncube, L.D., 2010, 'Ubuntu: A transformative leadership philosophy', Journal of Leadership Studies 4(3), 77-82. https://doi.org/10.1002/jls.20182

New World Encyclopedia, 2015, Responsibility, viewed 20 July 2019, from http:// www.newworldencyclopedia.org/p/index.php?title=Responsibility\&old id $=989284$.

Robbins, V.K., 1996, Exploring the texture of texts: A guide to socio-rhetorical interpretation, Trinity Press International, Harrisburg, PA.

Van Niekerk, B., 2018, 'The concept of chosen people in the construction and maintenance of Jewish identity', HTS Teologiese Studies/Theological Studies 74(3), a4947. https://doi.org/10.4102/hts.v74i3.4947 